\title{
防食塗装用物理的素地調整方法の最近の話題
}

\author{
青 木 茂* \\ * 千代田化工建設株式会社
}

\section{Topics on Mechanical Surface Preparation for Coating on Steel Structures}

\author{
Shigeru Aoki* \\ * Chiyoda Corporation
}

\begin{abstract}
Methods and effects on metal substrate to be coated on some of mechanical surface preparation, especially blasting, are described. And, after introducing recent action of ISO/ TC35/SC12 on this subject, correspondence as Japanese industries for the action of ISO is appealed.
\end{abstract}

Key words: coating, painting, surface preparation, blasting, evaluation, standard

\section{1.はじめに}

塗装や有機ライニングなどを鋼材表面に被覆する際 に，それらの皮膜品質を高める上で最も重要な工程の一 つとして “surface preperation”がある。ただ,この用 語に相当する日本語は実にさまざまであって, 数年前に (社)日本塗料工業会の内部で行われた関係者へのアンケ 一ト調査でも, 素地調整・下地処理・表面調整・表面処 理・前処理・ケレン・研掃・下地ごしらえなど 12 種類 の呼称が回答されたことがある。ここでは, 後述する ISO 対応国内委員会内部でほぼ定着しつつある素地調 整を使らこととする。

素地調整の目的は, 塗膜の付着に有害な被塗物上の異 物を取り除くことと, 塗料と被塗物との接触面積の拡大 や塗膜の母材への食付きを高めるための粗面化（肌荒ら し）を図ることであるが，その方法は化学的・物理的の 二つに大別される。前者は酸洗や化成皮膜処理であり, 主として工場内でのライン化された塗装に用いられてい る。後者は大型構造物の塗装などに利用されるもので, グラインダーやブラスト仕上げがその代表である。本稿 では, これらについての話題を紹介してみたい。

\section{2. ブラスト処理の方式}

ブラスト処理は，固い粒子を高速で被塗物にぶつけて その表面上の異物を除去する方法であり，その粒子（研 掃材といら人も多いが, 筆者は次項で述べる切削効果に

* 产221 横浜市神奈川区守屋町 3-13 (3-13, Moriyacho, Kanagawa-ku, Yokohama 221, Japan)
重点を打いて「研削材」の方が良いと考えている）の種 類と，粒子に高速のエネルギーを与光る方式とで表 1 に 示すよらに分類することができる。

この分類表で印を付忛たよらに，同じ研削材が別の方 式で用いられる場合も多いので, 従来慣用的に使われる ことのあったサンドブラストとショットブラストの 2 語 でブラスト処理方法のすべてを片付ける表現は好ましく ない。サンド (けい砂) を用いたエアーブラストとかシ ョットあるいはグリットを用いた遠心式ブラストといら ベきである。

な拈, 粉塺の飛散防止を狙って水(十インヒビタ一)を 併用する方式も広まりつつあるが，多量の水を用いる場 合には精密機械仕上げの液体ホーニングや最近の超高圧 水流による切断作用と原理的な共通面がある。

\section{3. ブラスト処理の効果}

被塗物に研削材が衝突した時の状況を定性的に描いて みたのが図 1 である。球状の研削材（ショット）は衝突 エネルギーの多くが周辺への打撃に変わるので, 比較的 広範囲のさび（ミルスケール：黒皮を含も）を飛ばすこ とができる。一般に沢山の粒子がアトランダムに平面に 当たる場合，時間の経過と共に同じ点に何回も当たって しまい，全面にくまなく当たらせるには長い時間が掛か るものであり, 一粒で広範囲のさびを除く性能は好まし いものである。しかし飛散するのは脆い上層部だけで， 下層のさびは残るし, 研削材直下のさびはその多くが母 材内部へ押し达秃れることとなる。 
表 1 ブラスト処理方法の分類

\begin{tabular}{|c|c|c|c|c|c|c|}
\hline \multirow{2}{*}{$\begin{array}{l}\text { 研削材を飛ば } \\
\text { すエネルギー }\end{array}$} & \multicolumn{2}{|r|}{ 代 } & 的 & 材 & & \multirow{2}{*}{$\begin{array}{c}\text { ブラスト方式 } 0 \\
\text { 名称 }\end{array}$} \\
\hline & $\begin{array}{l}\text { スチール } \\
シ ョ ッ ト\end{array}$ & $\begin{array}{l}\text { スチール } \\
\text { グリット }\end{array}$ & $\begin{array}{c}\text { サンドまたは } \\
\text { けい砂 }\end{array}$ & $\begin{array}{c}\text { からみまたは } \\
\text { スラグ }\end{array}$ & コランダム & \\
\hline \multirow[t]{2}{*}{ 圧縮空気 } & & \multirow[t]{2}{*}{$(\mathrm{O})$} & \multirow[t]{2}{*}{0} & \multirow[t]{2}{*}{0} & \multirow[t]{2}{*}{0} & エアーブラスト \\
\hline & & & & & & $\begin{array}{l}\text { (水添加の時) } \\
\text { 少量：リェット } \\
\text { 多量：スラッー }\end{array}$ \\
\hline 高王 水 & & & ○ & 0 & 0 & $\begin{array}{l}\text { ウォーター } \\
\text { ブラスト }\end{array}$ \\
\hline 回転川笽 & 0 & 0 & & & $(\bigcirc)$ & 遠心式ブラスト \\
\hline
\end{tabular}

○印は一般的に適用されている例

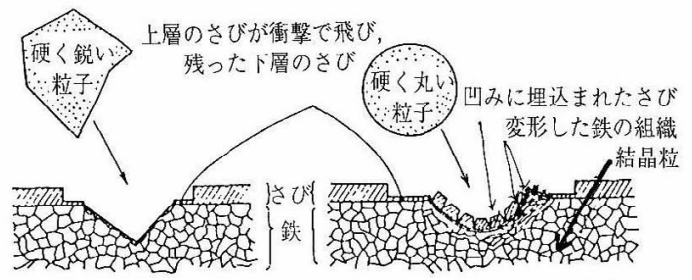

（a）鉄面を切削した場合

（b）鉄面を吒き潰した場合

図 1 ブラストした表面の断面の模式図

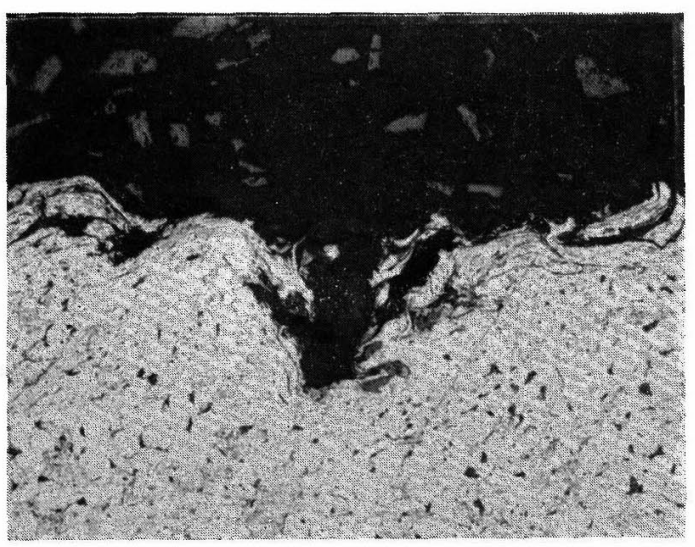

図 2 ブラスト仕上げ面の断面の一例 $(200 \times)$

鋭角を持った研削材は被塗物を削り取って行くので， 衝突エネルギーの多くが切削に使われ周辺のさびを飛ば す效果は少ない。つまり面積的な効率は琹いが，研削材 直下にさびを埋め込さ程度が少ない。また処理面の凹凹 は，図 2 に例示するよらに，球状研削材でのブラストに 比べて激しく鋭いので, 粗面化の効果も大きい。

ブラストの効果についてさびの除去として表現して来 たが，見えない異物としての塩分や硫酸根などもさび層 中に含まれる分は一緒に除かれる筈である。ただし，研
削材自身が破けて被塗物中にめりこさことも確認されて いる1)ので, 污れた研削材を使ったり, 繰返し使用した りしなければ，の話である。油脂分は衝撃時に移動する 可能性があるので, 付着が明らかな場合は事前に脱脂乙 ておかなくてはならない。脱脂はアルカリあるいは溶剤 洗浄が普通であるが, 火炎であぶるといらいささか乱暴 な方法もある。

な辌余談ながら, 砂漠の砂嵐から着想された（以前自 動車の空がラスがなくなってしまったテレビが放映され たことがある）といわれるブラスト処理は，墓石の名前 彫りやガラス工芸など他分野でる幅広く利用されてい る。

\section{4. ブラスト処理面の評価}

ブラスト処理後の仕上げ面は, 従来は除錆率と面粗さ とで評価されてきた2)。しかし前者は，目で見党る(例え 拡大鏡位使っても)異物の除去程度の表現であり,細かな 粉塵や塩分・硫酸根など見えない異物は一般はに問題に されてこなかった。ところがいしばらく前からこれれ彷 塗物の表面に残留していると淕膜の劣化が促進されるら

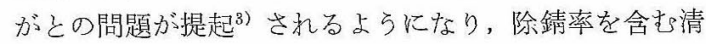
浄度 (英語では cleanliness) といら概念に変ってきた。 塗膜は一般に使用環境からの水分の透過老阻止し得な いものであるが，水と親和力の強い物質がその裏に存在 すると，透過が速められるらしい。塩分をなるべく残さ ぬ上らにとの考えは段々強くなっているよらで，素地調 整とはちょっと離れた話題であるが，一昨年米国NACE で制定された塗膜の湿式ピンホールテストの基準書で は，塗膜欠陷中に浸透させるべき導通液に，塩を入れて はいけないとまで書いている。るっともそのために，導 通液の電気抵抗が大きすぎて朋心の欠楩が検出できない といら根本的矛盾に満ちた基準になってしまっだが， それほど塩を恐れているという一例である。 
5. 物理的素地調整に関する ISO（国際規格）

\section{1 国際委員会の構成}

このように重要かつ問題のある素地調整について, 国 内ではこれまで公式な基準はなく，大ロユーザーが欧米 の除錆率に関する基準を流用・拡張して作成した団体規 格を制定していたに止まっていた。

欧米の基準で有名なものは，SIS（スウェーデン規格 協会）が発表した写真表示のものと，それを文章で表現 した SSPC（米国・鋼構造物塗装協会）の基準である。 前者は Sa 2; Sa 3, 後者は SP-5; SP-10 などと表現され て括り，馴染みの方も多いであろら。

ところが 10 年程前から, ブラストを中心とする素地 調整技術全般に関して系統的な国際規格 ISO を作る委 員会が組織され, 精力的な活動が続けられている。委員 会の構成を表 2 に示したが,WG 2 の主査は上記スウェ ーデン写真の作成者であり，また米国 SSPC も毎回有力 メンバーを派遣している。日本は第 5 回委員会からオブ

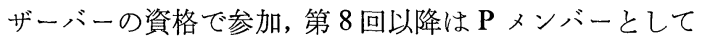
正式参加し、いろいろと発言してきた。

表 2 ISO/TC 35/SC 12 の構成と幹事国

\begin{tabular}{|c|c|c|c|}
\hline 委 員 会 名 & 作 業”担 当 & 幹 事 国 & 事務局 \\
\hline TC35/SC12 & $\begin{array}{l}\text { 鍙料及び関連 } \\
\text { 染装前 } \\
\text { の素地調整 }\end{array}$ & 英 & $\mathrm{BS}$ \\
\hline WG 1 & 表面粗さ & 英 & BS \\
\hline WG 2 & 清 浄 度 & スウェーデン & SIS \\
\hline WG 3 & 処理方法 & 独 & DIN \\
\hline WG 4 & 研 削 材 & 英 & BS \\
\hline AG-M & 金 属 系 & 英 & BS \\
\hline AG-NM & 非金属系 & 独 & DIN \\
\hline
\end{tabular}

ISO へはそれぞれの国の政府機関単位（日本は工業技 術院標準部が担当）で参加して，国際委員会には専門家 を委員として登録・派遣し，また回付されてくる原案へ 国として投票を行らこととなっている。本件の場合，実 際の審議活動は日本塗料工業会が事務局となって対応国 内委員会が設けられて和り，そこに関係ある協会・工業 会が国内委員を派遣している。委員長は, 初代が茨城大 学の長坂名誉教授で, 現在は東大・生産技術研究所の増 子教授が就任されている。国内委員会の下部には，ISO のWG 2 および WG 3 に対応するテーマ担当の WG-A とWG 4 に対応するテーマ担当の WG-B とが組織され ている。

\subsection{ISO の進展}

本年 4 月のニーゴスラビアで開催された第 11 回会合 では，これまでの活動がようやく実ってきた感じで, 従
来刊行された 2 件に加え, 6 件の ISO が刊行準備中で あることが確認され，また素地調整後の表面の清浄度や ブラスト用研削材などに関する規格原案にも大幅な進展 がみられた。その概要を表 3 に紹介する。詳細は別報5 を参照されたいが，これら全てが整備されると作業工程 に差し障りが出るのではとの皮肉が出るほど，盛り沢山 である。

これらの中で, 特に興味あるのは表面塩分の定量分析 と研削材の仕様・試験法とである。

前者について, 日本からも拭取り後の北川式検知管方 式を提案し CD となったが，スウェーデンの Bresle 氏 の発明になるサンプリング法は，単にこの目的だけでな く，表面付着物の採取が問題となるいろいろな場面で利 用され得るものである。要は周囲をスポンジで囲まれた 内径 $40 \mathrm{~mm}$ 程度のゴム製パッチを表面に張り付け, 注 射針で注入した水で表面の水溶性成分を吸い取る方式で あるが，壁や天井でも，またかなり窮屈な部分でも，な れれば水をこぼさずに採取することが出来る。なかなか のアイディア商品である。

研削材については金属系・非金属系のそれぞれに求め られる特性と,それら特性の試験方法を網羅すべく，審 議が精力的に続けられている。対象とする研削材と試験 方法についてまとめると以下の通りである。

○金属系研削材の種類

鋳鉄ショット, 高炭素鋼ショット・グリット，低 炭素鋼ショット

○金属系研削材の試験方法 サンプリング, 粒度, 硬さ, 密度, ミクロ構造, 異物, 湿気,パフォーマンス (繰返し使用可能回数) ○非金属系研削材の種類

けい砂，ス多オロライト，オリビンサンド，銅ス ラグ, 石炭灰スラグ, ニッケルスラグ, 製鉄スラ グ，溶融アルミナ

○非金属系研削材の試験方法

サンプリング，粒度，見掛け密度，硬さ，湿気， 水溶性污れ, フライアビリティー（砕けやすさ）

[注] 水溶性塩化物：WG-2/4 間で統一性検討。 かさ密度：他の ISO で代用可能。

これまで国内では，ブラスト用研削材としては金属系 の一部に JIS があり, 溶融アルミナなどが砥石用の JIS を持っていただけであったが，それらも現在 ISO で審 議しているよらな詳細な特性までは規定していない。そ の他の研削材はまったく野放しといってもよい状態であ った。したがって現状のままであれば，これらのISO に 適応した研削材を求めようとしても, 特性值の表示が不 十分なため購入不能な場合すら起こり得るものと思われ る。一連の内容が ISO となるのも間近と予想されるの 
表 3 素地調整用 ISO 規格化の進展状況

\begin{tabular}{|c|c|c|}
\hline 刊行・審議段階 & ISO No-Part No. & 標 題 （抄 訳） \\
\hline 刊行済み & $\begin{array}{l}8501-1 \\
8503-1,2,3,4\end{array}$ & $\begin{array}{l}\text { 鋼材の除錆率の目視判定用参考写真集 } \\
\text { 表面粗望比較板 }\end{array}$ \\
\hline 刊行準備中 & $\begin{array}{l}8501-2 \\
8502-1 \text { TR } \\
8502-2 \\
8504-1 \\
8504-2\end{array}$ & 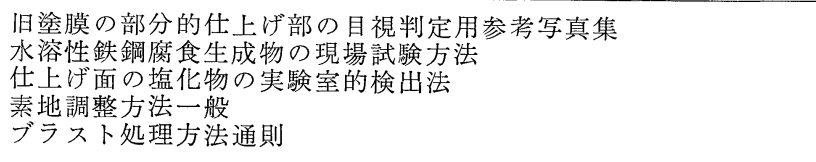 \\
\hline DIS 投票中 & $\begin{array}{l}8502-3 \\
8502-4\end{array}$ & $\begin{array}{l}\text { 仕上げ面のダストの評価方法 } \\
\text { 結露の危険性の予知方法 }\end{array}$ \\
\hline DIS となったもの & $\begin{array}{l}8504-3 \\
11124-2,3,4 \\
11125-1 \sim 7 \\
111261,3 \sim 6,8 \\
11127-1 \sim 6\end{array}$ & 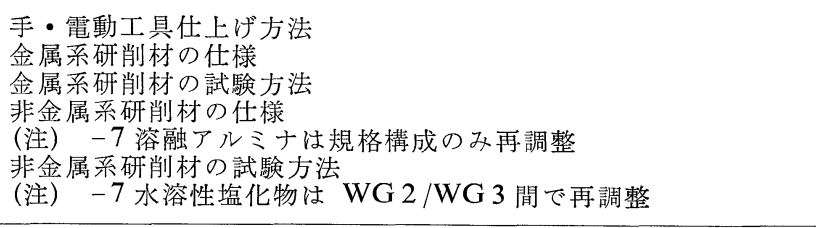 \\
\hline CD となったもの & $\begin{array}{l}8501-3 \text { TR } \\
8502-5 \\
8502-3 \\
11124-1\end{array}$ & 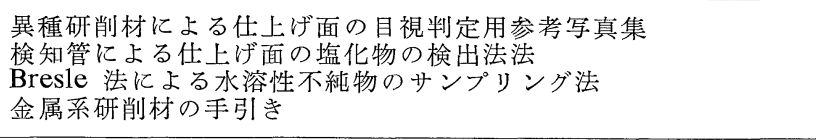 \\
\hline $\begin{array}{l}\text { NWI として採択 } \\
\text { されたもの }\end{array}$ & $\begin{array}{l}8501-4 \\
8501-5\end{array}$ & $\begin{array}{l}\text { ショッププライマー面の仕上げグレード } \\
\text { 溶接部等の仕上げグレード }\end{array}$ \\
\hline WD 作成予定 & $\begin{array}{c}8502-7 \\
\ldots \\
11126-2 \\
\ldots \\
\cdots\end{array}$ & 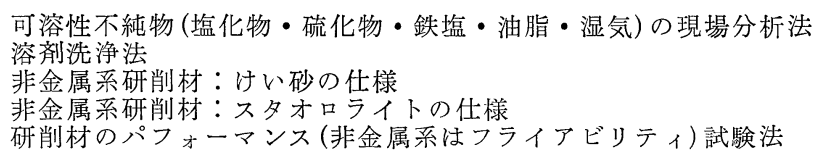 \\
\hline
\end{tabular}

\section{〔付〕ISO の審議段階}

\begin{tabular}{|c|l|l|}
\hline ISO & International Standad & 国際規格（ジュネーブの ISO 本部で管理） \\
- TR & Technical Report & 正式技術報告 : WG, SCで審議, 投票 \\
DIS & Draft of ISO & ISO 本部で投票管理（審議は SC) \\
CD & Committee Draft & SC レベルで投票管理（審議は WG) \\
NWI & New Work Item & SC レベルで投票管理（審議は WG) \\
WD & Working Draft & WG で審議するためめの原案 \\
\hline
\end{tabular}

で，国内メーカーの対応が急務であうう。

\section{3 国内対応策への提言}

上述のよらに素地調整に関する基本的 ISO が完成し, 引き続きとの他規格の審議が進展している。しかし国内 では, 素地調整が重要な工程であることはだれもが認め ていながら、ごく一部を除いてこれらに対応すべき公的 規格類はほとんど整備されていない。

これら ISO 規格に準拠しなければならないジョブは, 当面は国際間の取引きに限られるかもしれない。しかし 国内建設工事の国際解放が進めば国内向けの塗装作業に おいても「素地調整は ISO 以よること」と 1 行書かれ ただけの仕様書が出てくることも考光られる。午の時に なって担当者がかなりあわてても，らまく ISO 亿合致 した素地調整が出来なかったといらような事態も十分予 想し得るのではないだろらか。そんな場合, もし本当に
ISO に不合理な点があるならば，自国の規格であるJIS を確立して扣くことが一つの有力な対抗手段となろう。

しかも一方, 国際的には, 工業製品の標準を独自に作 り, 同じ土俵で勝負しょうとしない日本は不公平だと指 弾されている。したがって, 貿易摩擦解消の最良の潤滑 油の一つは JIS の ISO 化だといわれて拈り, 通産省で は ISO 審議に参画するとともに，ISO に沿った JIS の 整備を強く指導されているとのことである。

いずれにしても，技術的に重要でありながら未整備の 本分野に乱いては, ISO 制定に呼応し, 早急に JIS の作 成に向けて努力すべきであろう。その場合には，関連の 公団なぞ幅広いニーザーの参加も求め, 現在の ISO 対 応国内委員会とは別個の，あるいはとれを拡大した形で 組織した JIS 制定委員会の設置が必要と思われる。

私見ではあるが，上記 ISO の審議を参考とすれば， 
日本でも直ちに JIS の原案作りに取り掛かることが出来 るのではないだろらか。（1991 年 12 月 10 日受理）

\section{文献}

1) L. B. Doherty: Mater. Perform., 13 [11] 12 (1974).
2）青木 茂: 実務表面技術, 28 [ 9 ] 412 (1980).

3) C. Calabrese, \& J. R. Allen: Corrosion, 34 [10] 331 (1978).

4) 青木 茂: 防錆管理, 33 [ 5 ] 19 (1989).

5）青木 茂: 防錆管理, 35 [9] 26 (1991). 